UDK $577.1: 61$

ISSN 1452-8258

\title{
EFFECTS OF ZINC SUPPLEMENTATION ON SERUM COPPER TO ZINC AND CRP TO ALBUMIN RATIOS IN HEMODIALYSIS PATIENTS
}

\section{EFEKTI SUPLEMENTACIJE CINKOM NA ODNOSE SERUMSKOG BAKRA I CINKA I ODNOS CRP PREMA ALBUMINU KOD PACIJENATA NA HEMODIJALIZI}

\author{
Marwa Hajii1,2, Rania Khedher1,3, Mehdi Mrad ${ }^{1,4}$, Mohamed Bassem Hammami 1,2, Nawel Rafrafi ${ }^{5}$, \\ Salma Chouchi ${ }^{6}$, Moncef Feki ${ }^{1,2}$, Afef Bahlous ${ }^{1,4}$, Karim Zouaghi, ${ }^{1,3}$, Hayet Fellah ${ }^{1,2}$ \\ ${ }^{1}$ University of Tunis El Manar, Faculty of Medicine of Tunis, 1007 Tunis, Tunisia \\ ${ }^{2}$ Rabta University Hospital, Laboratory of Biochemistry, LR99ES11, 1007 Tunis, Tunisia \\ ${ }^{3}$ Rabta University Hospital, Department of Nephrology, 1007 Tunis, Tunisia \\ ${ }^{4}$ Pasteur Institute, Laboratory of Biochemistry, 1002 Tunis, Tunisia \\ ${ }^{5}$ Radial Hemodialysis Clinic, 2010 Manouba, Tunisia \\ ${ }^{6}$ Udial Hemodialysis Clinic, 1007 Tunis, Tunisia
}

\section{Summary}

Background: Zinc $(\mathrm{Zn})$ deficiency is a common condition and could contribute to poor outcomes in hemodialysis (HD) patients. The aim of this study was to evaluate the effects of $\mathrm{Zn}$ supplementation on serum copper $(\mathrm{Cu})$ to $\mathrm{Zn}$ and $\mathrm{C}$-reactive protein (CRP) to albumin ratios (CAR) in HD patients.

Methods: Seventy-seven HD patients were enrolled in a multicentre simple-blind randomized clinical trial. Only 37 HD patients completed the study; they were randomly divided into two groups and supplemented with zinc sulphate $(n=17)$ or placebo $(n=20)$ for two months. Serum $\mathrm{Zn}$ and $\mathrm{Cu}$ were measured by atomic absorption spectrophotometry. Serum albumin and hypersensitive-CRP were assessed by colorimetric and immunoturbidimetric method, respectively. Determinations were performed before and after supplementation.

Results: After two months of supplementation, serum $\mathrm{Zn}$ significantly increased, and $\mathrm{Cu}$ to $\mathrm{Zn}$ ratio decreased in $\mathrm{Zn}$ supplemented group, but remained unchanged in the placebo group. In parallel, serum albumin concentrations significantly increased, and CAR decreased in Zn supplemented group only.

\begin{abstract}
Kratak sadržaj
Uvod: Manjak cinka $(Z n)$ je uobičajeno stanje i može doprineti lošim ishodima kod pacijenata na hemodijalizi (HD). Cilj ove studije je bio da proceni efekte suplementacije $\mathrm{Zn}$ na odnos serumskog bakra (Cu) i $\mathrm{Zn}$ i odnos C-reaktivnog proteina (CRP) i albumina (CAR) kod pacijenata na hemodijalizi.

Metode: Sedamdeset i sedam pacijenata na hemodijalizi je uključeno u jednostruko - slepo i randomizovano kliničko ispitivanje u više centara. Samo 37 pacijenata na hemodijalizi je završilo studiju. U nasumično podeljene dve grupe počelo se sa suplementacijom $u$ ishrani cink sulfatom $(n=$ 17) ili placebom $(n=20)$ tokom dva meseca. Serum $Z n$ i $\mathrm{Cu}$ su mereni atomskom apsorpcionom spektrofotometrijom. Albuminski serum i hipersenzitivni CRP procenjeni su kolorimetrijskim i imunoturbidimetrijskim metodom, svaki posebno. Merenja su vršena i pre i posle suplementacije. Rezultati: Nakon dva meseca suplementacije $\mathrm{Zn}$ u serumu se značajno povećao, a odnos Cu i Zn smanjio u grupi gde je sprovođena suplemenacija Zn, ali je ostao nepromenjen u grupi sa placebom. Paralelno sa tim, koncentracije albumina u serumu značajno su porasle, a CAR se smanjio samo u grupi sa suplementacijom $\mathrm{Zn}$.
\end{abstract}

Address for correspondence:

Marwa Hajji

Rabta Hospital, Laboratory of Biochemistry, 1007 Jebbari,

Tunis, Tunisia

Tel/Fax: 21671561 912; Mobile: 21622761880

e-mail: marouahajji1@gmail.com

List of abbreviations: CAR, CRP to albumin ratio; CRP, C-reactive protein; $H D$, hemodialysis. 
Conclusions: $\mathrm{Zn}$ supplementation reduces $\mathrm{Cu}$ to $\mathrm{Zn}$ and CRP to albumin ratios in HD patients. These changes point towards an improvement in nutritional, oxidative and inflammatory status. The study findings suggest that correcting $\mathrm{Zn}$ deficiency reduces poor outcomes in HD patients.

Keywords: copper to zinc ratio, C-reactive protein to albumin ratio, hemodialysis, zinc supplement

\section{Introduction}

HD is associated with a high burden of poor cardiovascular outcomes and increased mortality (1). This has been associated with conditions such as malnutrition, inflammation and oxidative stress $(2,3)$. Zn is a trace element that is essential for human health. It regulates numerous enzyme activities and immune function and exerts antioxidant and anti-inflammatory effects $(4,5)$. It is involved in proteins and lipids metabolism, nucleic acids synthesis and oxygen transportation $(6,7)$. Zn deficiency, a common condition in HD patients, is associated with malnutrition, inflammation and oxidative stress (6-9) and thus could be an additional contributor to poor outcomes in HD patients (10). $\mathrm{Cu}$, another trace element, has a role in haemoglobin synthesis, immune function and defence against oxidants (11). It was shown that $\mathrm{Cu}$ and $\mathrm{Zn}$ interact antagonistically at high levels (12). Serum $\mathrm{Cu}$ to $\mathrm{Zn}$ ratio is considered a better marker for inflammation, oxidative stress and cardiovascular risk than serum $\mathrm{Zn}$ or $\mathrm{Cu}$ alone $(3,13)$. Elevated serum CRP and hypoalbuminemia are common in HD patients and were associated with adverse health effects in these patients (14-16). CAR is a biomarker of inflammation and nutrition. Elevated CAR reflects increased inflammation superimposed with malnutrition. It was shown to predict poor outcomes and increased mortality risk in patients with severe sepsis (17), cancer (18), acute coronary syndrome (19) as well as patients undergoing HD (20).

$\mathrm{Zn}$ supplementation was proved to ameliorate nutritional, inflammatory and oxidant status $(9,21$, 22). A previous study showed a decrease in $\mathrm{Cu}$ to $\mathrm{Zn}$ ratio in patients under dialysis following $Z n$ supplementation (9). However, the impact on CAR has never been investigated. The present study aimed to examine the effect of $Z n$ supplementation on serum $\mathrm{Cu}$ to $\mathrm{Zn}$ and CRP to albumin ratios.

\section{Material and Methods}

A multicentre randomized single-blind clinical trial was conducted among $77 \mathrm{HD}$ patients (45 men and 32 women) from February 2017 to March 2018. The patients were recruited from five centres: Rabta Hospital Nephrology department, Matri Hospital HD unit, Manouba HD Radial centre, Manouba HD public centre as well as HD Udial centre. An individual
Zaključak: Suplementacija Zn smanjuje odnos Cu u odnosu na Zn, i CRP u odnosu na albumin kod pacijenata na hemodijalizi. Ove promene ukazuju na poboljšanje statusa u vezi sa ishranom, oksidacijom i zapaljenjima. Nalazi studije sugerišu da smanjenje deficita $Z n$ umanjuje šanse za loše ishode kod pacijenata na hemodijalizi.

Ključne reči: odnos bakra prema cinku, odnos C-reaktivnog proteina i albumina, hemodijaliza, suplement cinka

clinical card was established on which personal data were collected. The eligibility criteria for patients to be enrolled were over 18 years of age, HD treatment for at least six months, HD performed three times per week (each for 4 hours) through a polysulfone membrane against a dialysis liquid containing the following ions: $\mathrm{Na}^{+}: 138 \mathrm{mmol} / \mathrm{L} ; \mathrm{K}^{+}: 2 \mathrm{mmol} / \mathrm{L} ; \mathrm{Ca}^{++}: 1.5$ $\mathrm{mmol} / \mathrm{L}_{;} \mathrm{Mg}^{++}: 0.5 \mathrm{mmol} / \mathrm{L} ; \mathrm{Cl}^{-}: 109 \mathrm{mmol} / \mathrm{L}$; $\mathrm{CH}_{3} \mathrm{CO}_{2}^{-}: 3 \mathrm{mmol} / \mathrm{L} ; \mathrm{HCO}_{3}^{-}: 35 \mathrm{mmol} / \mathrm{L}$. The clearance of urea evaluated by the ratio $\mathrm{Kt} / \mathrm{V}$ was 1.2 . The exclusion criteria were infection, gastrointestinal and liver diseases, congestive heart failure, cancer, psychiatric illness, pregnancy, use of immunosuppressants, corticoids, estrogens or contraceptives, as well as active smoking and alcoholism.

The patients were randomly divided into two groups; $43 \mathrm{HD}$ patients received one oral capsule containing $220 \mathrm{mg}$ of $\mathrm{Zn}$ sulphate $(100 \mathrm{mg}$ of elemental $Z n$ ) ( $Z n$ group), and $34 \mathrm{HD}$ patients received one oral capsule of similar appearance containing $220 \mathrm{mg}$ of maltodextrin. Capsules were taken daily after dinner during 60 consecutive days. Randomization was performed while stratifying on gender, 5 -year age class and duration of HD. Predialysis blood samples were obtained from all patients after a fast of 12 hours at inclusion (day 1) and after 60 days of supplementation (day 61). Serum Zn and Cu concentrations were determined by atomic absorption spectrophotometry (Perkin Elmer, Waltham, USA). Serum hypersensitive-CRP concentrations were determined by the immunoturbidimetric method using the Architect Cl8200 auto analyser (Abbott Diagnostics, Chicago, USA). Serum albumin was assessed by colorimetric method using Cobas Integra 400 auto-analyser (Roche Diagnostics, Meylan, France). The study protocol was approved by the Ethics committee of Rabta Hospital and all patients gave their informed and signed consent to participate in the study. A total of $37 \mathrm{HD}$ patients (17 in the supplemented group and 20 in the placebo group) completed the trial (Figure 1).

\section{Statistical analysis}

Statistical analyses were performed using the software package SPSS 22.0 for windows (SPSS Inc, Chicago, USA). Depending on the distribution of variables, data were reported as mean \pm standard devia- 


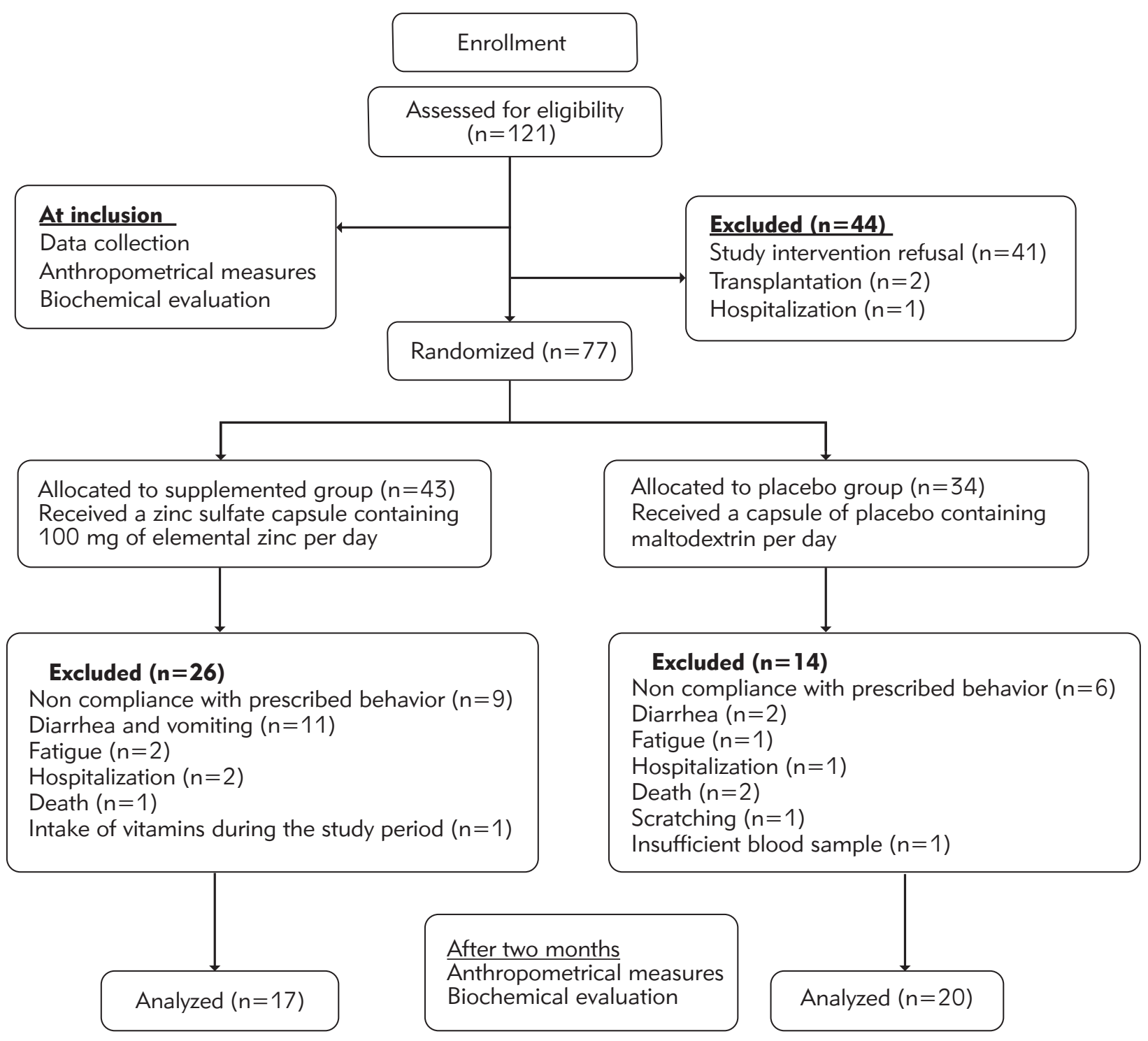

Figure 1 Flow chart for the process of hemodialysis patients selection.

tion (SD) or median (interquartile range). Betweengroup comparisons were made using independent ttest or Mann Whitney test, as appropriate. Withingroup comparisons of variables before and after supplementation were performed using paired t-test or Wilcoxon rank test, as appropriate. A p-value $<0.05$ based on two-sided calculation was considered significant.

\section{Results}

Baseline clinical and biochemical characteristics, including serum $\mathrm{Zn}$ concentrations and prevalence of hypozincemia (serum $\mathrm{Zn}<800 \mu \mathrm{g} / \mathrm{L}$ ), were comparable in $\mathrm{Zn}$ and placebo groups (Table I). After two months of supplementation, serum Zn concentrations increased and serum $\mathrm{Cu}$ concentrations and $\mathrm{Cu}$ to $\mathrm{Zn}$ ratio decreased in the $\mathrm{Zn}$ group but remained unchanged in the placebo group. Zn supplementation also resulted in a significant increase in serum albumin and decrease in CAR. Figure 2 shows an individual variation in $\mathrm{Cu}$ to $\mathrm{Zn}$ and CRP to albumin ratios under supplementation in $\mathrm{Zn}$ and placebo groups. 
Table I Baseline clinical and biochemical characteristics in zinc supplemented and placebo groups of hemodialysis patients.

\begin{tabular}{|l|c|c|c|}
\hline & Zinc group $(\mathrm{n}=17)$ & Placebo group $(\mathrm{n}=20)$ & $\mathrm{p}$ value \\
\hline Mean age, years & $52.9 \pm 13.5$ & $53.6 \pm 15.8$ & 0.89 \\
\hline Male gender, $\%$ & 70.6 & 55.0 & 0.33 \\
\hline Duration of & $6.65 \pm 3.93$ & $6.55 \pm 3.73$ & 0.93 \\
\hline Body mass index, $\mathrm{kg} / \mathrm{m}^{2}$ & $25.2 \pm 4.34$ & $26.4 \pm 5.74$ & 0.53 \\
\hline Serum creatinine, $\mu \mathrm{mol} / \mathrm{L}$ & $967 \pm 264$ & $896 \pm 361$ & 0.50 \\
\hline Serum albumin, $\mathrm{g} / \mathrm{L}$ & $37.1 \pm 2.17$ & $37.2 \pm 3.62$ & 0.90 \\
\hline Serum CRP, $\mathrm{mg} / \mathrm{L}$ & $3.90(14.9)$ & $5.90(13.95)$ & 0.85 \\
\hline Serum CRP to albumin ratio & $0.09(0.41)$ & $0.15(0.35)$ & 0.88 \\
\hline Serum zinc, $\mu \mathrm{g} / \mathrm{L}$ & $768 \pm 166$ & $812 \pm 168$ & 0.42 \\
\hline Zinc deficiency,$\%$ & 64.7 & 55.0 & 0.55 \\
\hline Serum copper, $\mu \mathrm{g} / \mathrm{L}$ & $1160 \pm 332$ & $1170 \pm 281$ & 0.91 \\
\hline Serum copper to zinc ratio & $1.52 \pm 0.38$ & $1.47 \pm 0.35$ & 0.62 \\
\hline
\end{tabular}

Values are expressed as mean $\pm \mathrm{SD}$ or median (interquartile range); CRP, C-reactive protein; *, serum $\mathrm{Zn}<800 \mu \mathrm{g} / \mathrm{L}$

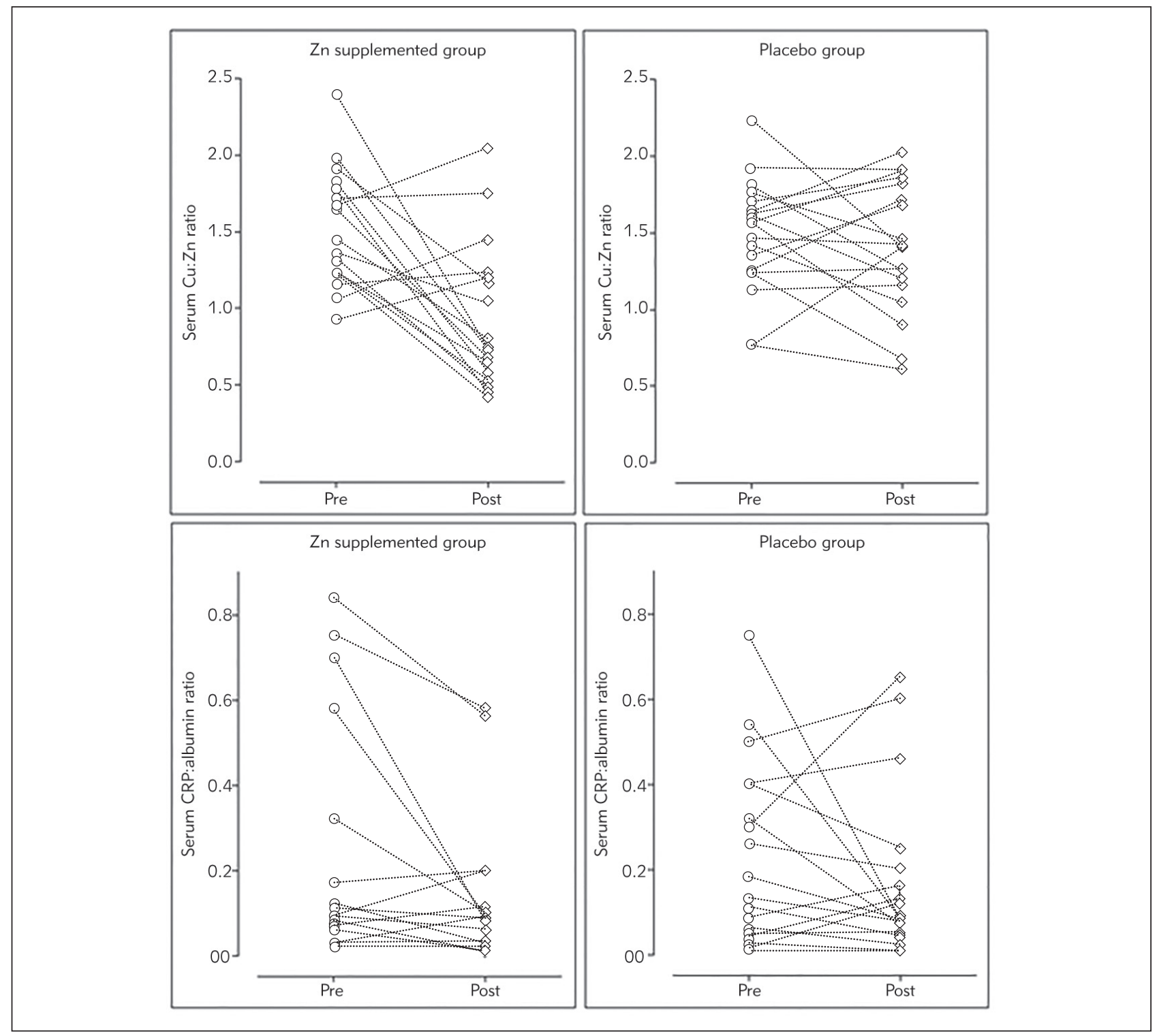

Figure 2 Changes in serum copper to zinc and C-reactive protein to albumin ratios in hemodialysis patients after two months of zinc supplementation. 


\section{Discussion}

Our study showed that $\mathrm{Zn}$ deficiency is common in Tunisian HD patients with a prevalence of $59.5 \%$. This result is consistent with the findings of previous studies which reported $\mathrm{Zn}$ deficiency in more than $50 \%$ of HD patients (23-25). Hypozincemia may result from $\mathrm{Zn}$ removal during $\mathrm{HD}$ treatment, reduced gastrointestinal absorption, low dietary intake and increased urinary excretion as well as protein restriction, increased expression of intracellular metallothioneins, and multi-infections $(3,21,26)$.

Zn supplementation in these HD patients resulted in an increase in serum $\mathrm{Zn}$ and a decrease in $\mathrm{Cu}$ to $\mathrm{Zn}$ ratio, which is also consistent with literature data $(9,21)$. If the improvement in $Z n$ status following $\mathrm{Zn}$ supplementation is expected and comprehensible, the decrease in serum Cu could be explained by competition between the two trace elements at the phases of intestinal absorption and cellular trafficking. Indeed, $\mathrm{Zn}$ and $\mathrm{Cu}$ share the same enterocyte membranes' transporters and intracellular trafficking proteins $(11,12)$. The competition may explain the decrease in $\mathrm{Cu}$ to $\mathrm{Zn}$ ratio following $\mathrm{Zn}$ supplementation. A high $\mathrm{Cu}$ to $\mathrm{Zn}$ ratio reflects oxidative stress, increased inflammation and immune dysfunction (12, $13,27)$. Thus, its reduction in HD patients is considered beneficial, which supports the usefulness of $\mathrm{Zn}$ supplementation in these patients.

The study also showed an increase in serum albumin and a reduction in CAR following $Z n$ supplementation. $\mathrm{Zn}$ and $\mathrm{Cu}$ are known to influence the function of immune cells and the secretion of cytokines (26). Zn exerts anti-inflammatory effects through downregulation of NF-B, leading to a reduction in proin ammatory cytokines (28). Zn deficiency was shown to induce a decrease in CD4: CD8 ratio and the number of B-cells (29). However, Zn supplementation was demonstrated to increase cells expressing CD19 (9). Cu excess is considered potentially proinflammatory by inducing oxidative stress $(30,31)$. CAR combines levels of CRP and albumin, a positive and a negative protein of acute phase inflammation, respectively. The reduction in the inflammatory response associated with $\mathrm{Cu}$ to $\mathrm{Zn}$ ratio

\section{References}

1. Wright Alastair Hutchison J. Cardiovascular disease in patients with chronic kidney disease. Vas Heal and Risk Manag 2009; 5: 713-22.

2. Fung F, Sherrard DJ, Gillen DL, et al. Increased risk for cardiovascular mortality among malnourished end-stage renal disease patients. Am J Kidney Dis 2002; 40: 30714.

3. Guo CH, Chen PC, Yeh MS, Hsiung DY, Wang CL. $\mathrm{Cu} / \mathrm{Zn}$ ratios are associated with nutritional status, oxidative stress, inflammation, and immune abnormalities in decrease may inhibit the synthesis of positive proteins of acute phase inflammation including CRP and stimulate the synthesis of negative proteins of acute phase inflammation such as albumin. Our results are consistent with the findings of previous studies which reported a reduction in serum CRP concentrations $(9,21)$ and an increase in serum albumin after $\mathrm{Zn}$ supplementation $(9,32)$. However, no previous study has investigated the impact on the ratio in HD patients.

The study has some limitations. First, the small sample size might have lowered the statistical power of the study. In fact, a number of patients in both $\mathrm{Zn}$ and placebo groups dropped out from the trial for lack of compliance with the study design or due to adverse health effects. HD patients were supplemented without taking into account their baseline serum $\mathrm{Zn}$ concentrations. This might explain some side effects that occurred in some patients. Further, trials with large sample size in $\mathrm{Zn}$ deficient patients are needed to confirm our results.

In conclusion, $\mathrm{Zn}$ supplementation in HD patients resulted in a decrease in $\mathrm{Cu}$ to $\mathrm{Zn}$ and CRP to albumin ratios. Such modifications point towards an improvement of nutritional, inflammatory and oxidative status. The study findings suggest that $\mathrm{Zn}$ supplementation is beneficial in HD patients and may contribute to reduce poor outcomes and improve the survival and quality of life in these patients. Therefore, patients on HD should be screened for Zn deficiency, and any deficiency should be adequately corrected.

Acknowledgements. The authors gratefully acknowledge the patients and administrative, nursing and technical staff for their valuable help. Special thanks to »Vital Laboratory« for providing Zn sulphate and placebo.

The study was supported by funds of Research Laboratory LR99ES11, Ministry of Higher Education and Scientific Research of Tunisia.

\section{Conflict of interest statement}

The authors declare that they have no conflicts of interest in this work. patients on peritoneal dialysis. Clin Biochem 2011; 44: 275-80.

4. Sun JY, Jing MY, Wang JF, et al. Effect of zinc on biochemical parameters and changes in related gene expression assessed by cDNA microarrays in pituitary of growing rats. Nutrition 2011; 22: 187-96.

5. Prasad AS. Clinical, Immunological, anti-inflammatory and antioxidant roles of zinc. Exp Gerontol 2008; 43: 370-7. 
6. Jern NA, VanBeber AD, Gorman MA, Weber CG, Liepa GU, Cochran CC. The effects of zinc supplementation on serum zinc concentration and protein catabolic rate in hemodialysis patients. J Ren Nutr 2000; 10: 148-53.

7. Ribeiro RC, Sales VS, Neves FAR, Draibe S, BrandaoNeto J. Effects of Zinc on Cell-Mediated Immunity in Chronic Hemodialysis Patients. Biol Trace Elem Res 2004; 98: 209-18.

8. Fellah $H$, Feki $M$, Soussi $M$, et al. Oxidative stress in endstage renal disease: evidence and association with cardiovascular events in Tunisian patients. Tunis Med 2006; 84: 724-9.

9. Guo $\mathrm{CH}$, Wang $\mathrm{CL}$. E ects of zinc supplementation on plasma copper/zinc ratios, oxidative stress, and immunological status in hemodialysis patients. Int J Med Sci 2013; 10: 79.

10. Miao X, Wang Y, Sun J, et al. Zinc protects against diabetes-induced pathogenic changes in the aorta: Roles of metallothionein and nuclear factor (erythroid-derived 2)like 2. Cardiovasc Diabetol 2013; 12: 54.

11. Maggini S, Wintergerst ES, Beveridge S, Hornig DH. Selected vitamins and trace elements support immune function by strengthening epithelial barriers and cellular and humoral immune responses. Br J Nutr 2007; 98: 29-35.

12. Sudha R, Ponsuganthi K, Jones R. Serum zinc and copper levels in maintenance haemodialysis patients and its relationship with depression and anxiety. Global Journal of Medicine and Public Health 2015; 4.

13. Karahan SC, Deger O, Orem A, Ucar F, Erem C, Alver A. The effects of impaired trace element status on polymorphonuclear leukocyte activation in the development of vascular complications in type 2 diabetes mellitus. Clin Chem Lab Med 2001; 39: 109-15.

14. Yeun JY, Levine RA, Mantadilok V, Kaysen GA. C-reactive protein predicts all-cause and cardiovascular mortality in hemodialysis patients. Am J Kidney Dis 2000; 35: 469_ 76.

15. Kawaguchi T, Tong L, Robinson BM, et al. C-reactive protein and mortality in hemodialysis patients: the dialysis outcomes and practice patterns study (DOPPS). Nephron Clin Pract 2011; 117: 167-78.

16. Poon PYK, Szeto CC, Kwan BCH, Chow KM, Li PKT. Relationship between CRP polymorphism and cardiovascular events in Chinese peritoneal dialysis. Clin J Am Soc Nephrol 2012; 7: 304-9.

17. Kim MH, Ahn JY, Song JE, et al. The C-reactive protein/ albumin ratio as an independent predictor of mortality in patients with severe sepsis or septic shock treated with early goal-directed therapy. PLoS One 2015; 10: e0132109.

18. Wu M, Guo J, Guo L, Zuo Q. The C-reactive protein/ albumin ratio predicts overall survival of patients with advanced pancreatic cancer. Tumour Biol 2016; 37: 12525-33
19. Çağdaş M, Rencüzoğullari I, Karakoyun S. Assessment of relationship between $\mathrm{C}$-reactive protein to albumin ratio and coronary artery disease severity in patients with acute coronary syndrome. Angiology 2017; 70: 361-8.

20. Jyh-Chang H, Ming-Yan J, Yi-Hua L, Charn-Ting W. Precedent fluctuation of serum hs-CRP to albumin ratios and mortality risk of clinically stable hemodialysis patients. PLoS One 2015; 10: e0120266.

21. Rashidi AA, Salehi M, Piroozmand A, Sagheb MM. Effects of zinc supplementation on serum zinc and CReactive Protein concentrations in hemodialysis patients. J Ren Nutr 2014; 19: 475-8.

22. Argani H, Mahdavi R, Ghorbani-Haghjo A, Razzaghi E, Nikniaz L, Ghaemmaghami SJ. Effects of zinc supplementation on serum zinc and leptin levels, BMI, and body composition in hemodialysis patients. J Trace Elem Med Biol 2014; 28: 35-8.

23. Erten Y, Kayatas M, Sezer S, et al. Zinc deficiency: prevalence and causes in hemodialysis patients and effect on cellular immune response. Trans Proc 2010; 30: 850-2.

24. Dashti-Khavidaki S, Khalili H, Vahedi SM, LessanPezeshki M. Serum zinc concentrations in patients on maintenance hemodialysis and its relationship with anemia, parathyroid hormone concentrations and pruritus severity. Saudi J Kidney Dis Transpl 2010; 21: 641-5.

25. Shiota J, Tagawa H, Izumi N, Higashikawa S, Kasahara $H$. Effect of zinc supplementation on bone formation in hemodialysis patients with normal or low turnover bone. Ren Fail 2015; 37: 57-60.

26. Bozalioglu S, Ozkann Y, Turan M, Simsek B. Prevalence of zinc deficiency and immune response in short-term hemodialysis. Trace Elem Med Biol 2005; 8: 243-49.

27. Malavolta M, Giacconi R, Piacenza F, et al. Plasma copper/zinc ratio: an inflammatory/nutritional biomarker as predictor of all-cause mortality in elderly population. Biogerontology 2010; 11: 309-19.

28. De Martin R, Hoeth M, Hofer-Warbinek R, Schmid JA. The transcription factor NF- $B$ and the regulation of vascular cell function. Arterioscler Thromb Vasc Biol 2000; 20: 83-8.

29. Haase H, Rink L. The immune system and the impact of zinc during aging. Immun Ageing 2009; 6: 9.

30. Wintergerst ES, Maggini S, Hornig DH. Contribution of selected vitamins and trace elements to immune function. Ann Nutr Metab 2007; 51: 301-23.

31. Guo CH, Wang CL, Chen PC, Yang TC. Linkage of some trace elements, peripheral blood lymphocytes, inflammation, and oxidative stress in ESRD patients undergoing either hemodialysis or peritoneal dialysis. Periton Dialysis 2011; Int 31: 583-59.

32. Ghaemmaghami J, Mahdavi R, Faramarzi E, Mohammadpour N, Argani $\mathrm{H}$. Does zinc supplementation improve dietary intake, symptoms of eating problems, and serum zinc levels in hemodialysis patients? Dial Transplant 2010; 39: 530-3. 